\section{'Ruddy': A Multiple-pest-resistant Sweetpotato}

\author{
Janice R. Bohac ${ }^{\mathbf{1}}$ and D.M. Jackson ${ }^{2}$ \\ U.S. Vegetable Laboratory, Agricultural Research Service, U.S. Department \\ of Agriculture, Charleston, SC 29414
}

\author{
John D. Mueller ${ }^{3}$ \\ South Carolina Agriculture and Forestry Research System, Clemson University, \\ Clemson, SC 29817
}

\section{P.D. Dukes, $\mathrm{Sr}^{4}$}

U.S. Vegetable Laboratory, Agricultural Research Service, U.S. Department of Agriculture, Charleston, SC 29414

Additional index words. vegetable breeding, Ipomoea batatas, disease resistance, nematode resistance, soil insect resistance

The sweetpotato [Ipomoea batatas (L.) Lam.] 'Ruddy' was developed jointly by the U.S. Dept. of Agriculture (USDA), Agricultural Research Service (ARS), and the South Carolina Agriculture Forestry Research System. 'Ruddy' is an attractive, red-skinned, orange-fleshed cultivar with multiple resistance to diseases, nematodes, and soil insects. It has high yield potential and excellent baking quality. It will provide a multiple pest-resistant alternative to the red-skinned, pest-susceptible commercial cultivars Diane in California, and Georgia Jet in South Carolina and Georgia. It also gives organic growers an alternative cultivar to the pest-resistant cultivar Regal.

\section{Origin}

'Ruddy' originated as a seedling of maternal parent W-119 from an open-pollinated polycross of 30 other parental selections. This cultivar was tested as W-287 in South Carolina and in the National Sweetpotato Collaborators Trials. All parental lines were selected for high levels of multiple-pest resistance combined with an array of good horticultural traits.

\section{Description}

The leaves of 'Ruddy' are medium green, entire, cordate to triangular in shape with very slight teeth. The leaf blade has a prominent dark purple vein on the lower surface only at

Received for publication 28 Dec. 2000. Accepted for publication 21 May 2002. Technical contribution no. 4673 of the South Carolina Agriculture and Forestry Research System. The assistance of Research Entomologist Alvin Simmons and Agricultural Research Technicians J.F. Fender, B. Davis, and L.J. Still are gratefully acknowledged.

${ }^{1}$ Research Geneticist; to whom reprint requests should be addressed. E-mail address: JBohac@ awod.com

${ }^{2}$ Research Entomologist.

${ }^{3}$ Professor

${ }^{4}$ Research Plant Pathologist (retired). the juncture of the petiole. The plants are vigorous and leaf canopies are very dense and vigorous, shading the ground. Several years of observation in South Carolina have shown that the bedded roots sprout rapidly in the spring, and plant production per bushel of seed roots is greater than the commercially grown U.S. cultivar Beauregard.

\section{Disease and Insect Resistances}

'Ruddy' has good multiple resistance to many of the important diseases and insect pests of the crop. The ratings for insect and disease resistance were performed as described in Jones et al. (1981, 1986). It is resistant to the

Table 1. Response of 'Ruddy' and standard control sweetpotato cultivars to Meloidogyne incognita-Races 1 and 3 (greenhouse test) and natural populations (field test).

\begin{tabular}{lccc}
\hline \hline & \multicolumn{3}{c}{ M. incognita $($ Races 1\&3) } \\
\cline { 2 - 4 } Entry $^{\mathrm{x}}$ & $(1-5)$ & EMI $^{\mathrm{y}}$ & $\begin{array}{c}\text { Overall }^{\mathrm{z}} \\
\text { rating }^{\mathrm{w}}\end{array}$ \\
\hline Ruddy & 1.0 & 1.1 & $\mathrm{HR}$ \\
Beauregard & 4.7 & 4.7 & $\mathrm{~S}$ \\
Jewel & 1.7 & 1.9 & $\mathrm{R}$ \\
Sumor & 1.0 & 1.0 & $\mathrm{HR}$ \\
PI399163 & 1.0 & 1.0 & $\mathrm{HR}$ \\
LSD $(P=0.05 \%)$ & 1.1 & 1.1 & \\
\hline
\end{tabular}

${ }^{\mathrm{Z}}$ Gall index. Plants rated on scale of 1 to $5 ; 1=$ no galling and $5=$ severe galling.

${ }^{y}$ Egg mass index. Plants rated on a scale of 1 to $5 ; 1=$ no egg masses and $5=$ large number of egg masses.

${ }^{x}$ Ten selected, terminal, field-grown vine cuttings of each entry were used in four replications of a randomized complete-block design for each test. Eggs from Race 1 and Race 3 were extracted from PA-136 and mixed in equal numbers just prior to inoculation. The soil around each cutting was inoculated with $\approx 2500$ freshly extracted $M$. incognita eggs. After $60 \mathrm{~d}$, roots were dug, washed, and evaluated under $5 \times$ magnification (methods in Dukes et al., 1993a).

${ }^{\text {w } O v e r a l l ~ r a t i n g s ~ f o r ~} M$. incognita Races 1 and 3: SS $=$ Super Susceptible; $\mathrm{S}=$ Susceptible; $I R=$ Intermediate in Resistance; $\mathrm{R}=$ Resistant; HR = Highly Resistant; VHR = Very Highly Resistant. southern root-knot nematode, Meloidogyne incognita (Kofoid \& White) Chitwood, races 1 and 3 (Table 1) (Dukes et al., 1993a). 'Ruddy' is intermediate in resistance to Fusarium wilt, caused by Fusarium oxysporum f. sp. batatas (Wr.) Snyd. \& Hans (Table 2) (Dukes et al., 1993b). 'Ruddy' was observed to be free of symptoms of internal cork and russet crack (caused by strains of the sweet potato feathery mottle virus) under field conditions where symptoms were exhibited by the susceptible cultivar Porto Rico. 'Ruddy' was not tested for resistance to Streptomyces. Methods of disease testing and evaluation are described in Jones et al. (1986).

The levels of resistance of 'Ruddy' to damage by the Wireworm-Diabrotica-Systena (WDS) complex are very high compared to the susceptible control line SC1149-19 and similar to the resistant cultivar Regal (Table 3) (Jones et al., 1985). The WDS complex includes the southern potato wireworm (Conoderus falli, Lane), tobacco wireworm, (Conoderus vespertinus Fabricius), banded cucumber beetle (Diabrotica balteata Le Conte), spotted cucumber beetle (D. undecimpunctata howardi Barber), elongate flea beetle (Systena elongata Fabricius), and pale striped flea beetle (S. blanda Melsheimer and S. frontalis Fabricius). Compared to the resistant cultivar Regal and susceptible control breeding line SC1149-19, 'Ruddy' has moderate resistance to the sweetpotato flea beetle (Chaetocnema confinis Crotch) and the larvae of a white grub (Plectris aliena Chapin).

Table 2. Reaction of 'Ruddy' and standard control sweetpotato cultivars to stem rot Fusarium oxysporum f. sp. batatas (greenhouse test).

\begin{tabular}{lccc}
\hline \hline & \multicolumn{3}{c}{ F. oxysporum f. sp. batatas } \\
\cline { 2 - 4 } & $\begin{array}{c}\text { Disease } \\
\text { index } \\
\text { (0-5) }\end{array}$ & $\begin{array}{c}\text { Percent } \\
\text { killed }^{z} \\
(\% \text { of } \\
\text { Porto Rico) }\end{array}$ & Rating $^{\mathrm{w}}$ \\
Entry $^{\mathrm{x}}$ & 1.0 & 35 & IR \\
\hline Ruddy & 4.3 & 100 & SS \\
Sulfur & 3.5 & 100 & $\mathrm{~S}$ \\
Porto Rico & 0.5 & 35 & IR \\
Sumor & 0.0 & 0 & VHR \\
Excel & 0.3 & 15 & HR \\
Jewel & 0.7 & 25 & \\
LSD $(P=0.05 \%)$ &
\end{tabular}

'Percent killed determined when all 'Porto Rico' plants were dead.

${ }^{y}$ Disease index. Plants rated on a scale of 1 to 5, where $0=$ no disease after $21 \mathrm{~d}$, and $5=$ all plants killed in $7 \mathrm{~d}$.

${ }^{x}$ Vine cuttings with intact terminal buds were selected and cut from field-grown plants. Each cutting was trimmed and rooted in greenhouse benches containing sandy soil. For each entry four replicates, including 10 cuttings per replication, were arranged in a randomized complete-block design. Each cutting was dip-inoculated in a fresh aqueous suspension of spores $(150,000 / \mathrm{mL})$ for $30 \mathrm{~s}$ and planted. Disease data were taken daily for $21 \mathrm{~d}$ after planting (methods in Dukes et al., 1993b).

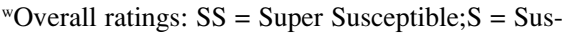
ceptible; IR = Intermediate in Resistance; $\mathrm{R}=$ Resistant, HR = Highly Resistant, VHR = Very Highly Resistant. 


\section{Performance}

Under South Carolina growing conditions, 'Ruddy' was a high-yielding cultivar, similar to 'Regal', and between the standard cultivars Beauregard and Jewel (Table 4). 'Ruddy's performance in other states varied. In 1998, yields for 'Ruddy' were higher than for 'Beauregard' in California and Kansas, and the same as for 'Beauregard' in California in 1997 (not tested in Kansas). However, yields for 'Ruddy' were much lower in other states like Alabama and North Carolina (McLaurin, 1998, 1999). This indicates that this cultivar has good yield potential. But it is unknown if its poor performance in some states is due to lack of adaptation to the growing conditions in those states, or whether yield could be increased with specific horticultural techniques.

The storage roots of 'Ruddy' grown under South Carolina conditions are fusiform and uniformly shaped with an attractive red skin and medium orange flesh. Under very dry soil conditions, 'Ruddy' is highly resistant to cracking, compared to the red-skinned 'Regal' (data not shown). The baked roots are sweet and moist with excellent baking quality and flavor, comparable to 'Jewel'. Storage roots of 'Ruddy' have $\approx 18 \%$ dry matter and keep well under long-term storage. In the plant beds, 'Ruddy' sprouts well, similar to 'Jewel'.

\section{Availability}

Foundation seed roots, sprouts, and cuttings of 'Ruddy' will be available in limited quantities to breeders and other researchers for the 2003 crop season. Requests for plant material should be made to Janice Bohac, U.S. Vegetable Laboratory, 2875 Savannah Highway, Charleston, SC 29414. Genetic material of this release will be deposited in the Sweetpotato Clonal Repository, Southern Regional Plant Introduction Station, 1109 Experiment St., Griffin, GA 3223-1791.

\section{Literature Cited}

Dukes, P.D., J.R. Bohac, J.M. Schalk, and J.D. Mueller, 1993a. Sweetpotato (Ipomoea batatas) southern root knot; Meloidogyne incognita (races 1\&3). Biological and cultural tests. APS Press 8:32.

Dukes, P.D., J.R. Bohac, and J.D. Mueller, 1993b. Sweetpotato (Ipomoea batatas) southern root knot; stem rot; Fusarium oxysporum f. sp. batatas. Biological and cultural tests. APS Press $8: 33$.

Jones, A., P.D. Dukes, J.M. Schalk, M.G. Hamilton, M.A. Mullen, R.A. Baumgardner, D.R. Paterson, and T.E. Boswell. 1985. 'Regal' sweetpotato. HortScience 20:781-782.

Table 3. Comparison of soil insect resistance of 'Ruddy' to standard breeding lines and cultivars.

\begin{tabular}{|c|c|c|c|c|}
\hline Entry $^{z}$ & $\begin{array}{l}\text { Uninjured } \\
\text { roots }(\%)\end{array}$ & $\begin{array}{c}\text { WDS severity } \\
\text { index }^{y}\end{array}$ & $\begin{array}{l}\text { SPFB-damaged } \\
\text { roots }^{\mathrm{x}}\end{array}$ & $\begin{array}{c}\text { Grub-damaged } \\
\text { roots }^{\mathrm{w}}\end{array}$ \\
\hline Ruddy & $35.4 \mathrm{~b}$ & $0.9 \mathrm{c}$ & $13.8 \mathrm{~b}$ & $3.0 \mathrm{~b}$ \\
\hline Regal & $48.8 \mathrm{~b}$ & $0.8 \mathrm{c}$ & $3.0 \mathrm{c}$ & $2.7 \mathrm{~b}$ \\
\hline Jewel & $13.2 \mathrm{ab}$ & $1.2 \mathrm{~b}$ & $3.9 \mathrm{c}$ & $8.9 \mathrm{ab}$ \\
\hline $\begin{array}{l}\text { SC1149-19 } \\
(P=0.05)^{\mathrm{v}}\end{array}$ & $0.0 \mathrm{a}$ & $2.7 \mathrm{a}$ & $44.5 \mathrm{a}$ & $11.7 \mathrm{a}$ \\
\hline
\end{tabular}

${ }^{2}$ Ratings taken on trial grown in Charleston, S.C.

'Wireworm, Diabrotica, Systena (WDS) complex; severity index: 1= 1-5 scars; $2=6-10$ scars; 4 $=>10$ scars averaged over all roots. This weighted index gives a higher score to roots with a larger number of scars. It was found over a number of years that this results in more rapid progress in increasing WDS resistance in the breeding population (Jones et al., 1986).

${ }^{\mathrm{x}}$ Sweetpotato flea beetle, rated as percentage of total roots with flea beetle damage.

${ }^{\text {w}}$ Plectris aliena, rated as percentage of total roots with grub damage.

"Means separation within columns by Duncan's new multiple range test (significance level, $P=$ $0.05)$

Table 4. Yield of the cultivar 'Ruddy compared to control cultivars tested in Blackville, S.C. ${ }^{2}$

\begin{tabular}{|c|c|c|c|c|}
\hline Cultivar & Ones $^{y}$ & Canners $^{\mathrm{x}}$ & Jumbos $^{\mathrm{w}}$ & TMY $^{\mathrm{v}}$ \\
\hline \multicolumn{5}{|c|}{ Trial I-1996 } \\
\hline Ruddy & $20.1 \mathrm{ab}^{\mathrm{u}}$ & $10.7 \mathrm{a}$ & $0.5 \mathrm{a}$ & $31.4 \mathrm{ab}$ \\
\hline Beauregard & $17.5 \mathrm{ab}$ & $11.1 \mathrm{a}$ & $0.5 \mathrm{a}$ & $33.2 \mathrm{a}$ \\
\hline Jewel & $11.7 \mathrm{~b}$ & $7.6 \mathrm{a}$ & $0.6 \mathrm{a}$ & $20.0 \mathrm{~b}$ \\
\hline Regal & $25.7 \mathrm{a}$ & $8.0 \mathrm{a}$ & $0.6 \mathrm{a}$ & $34.3 \mathrm{a}$ \\
\hline \multicolumn{5}{|c|}{ Trial II-1997 } \\
\hline Ruddy & $33.1 \mathrm{a}$ & $7.3 \mathrm{bc}$ & $3.3 \mathrm{a}$ & $43.7 \mathrm{a}$ \\
\hline Beauregard & $36.0 \mathrm{a}$ & $9.1 \mathrm{ab}$ & $5.0 \mathrm{a}$ & $50.0 \mathrm{a}$ \\
\hline Jewel & $30.3 \mathrm{a}$ & $11.1 \mathrm{a}$ & $2.3 \mathrm{a}$ & $43.7 \mathrm{a}$ \\
\hline Regal & $33.4 \mathrm{a}$ & $6.4 \mathrm{c}$ & $5.7 \mathrm{a}$ & $45.5 \mathrm{a}$ \\
\hline \multicolumn{5}{|c|}{ Trial III-1998 } \\
\hline Ruddy & $9.0 \mathrm{ab}$ & $12.7 \mathrm{a}$ & $0.0 \mathrm{~b}$ & $21.7 \mathrm{ab}$ \\
\hline Beauregard & $20.0 \mathrm{a}$ & $12.0 \mathrm{a}$ & $3.9 \mathrm{a}$ & $35.9 \mathrm{a}$ \\
\hline Jewel & $14.7 \mathrm{ab}$ & $9.0 \mathrm{a}$ & $0.0 \mathrm{~b}$ & $23.7 \mathrm{ab}$ \\
\hline Regal & $7.3 \mathrm{~b}$ & $11.5 \mathrm{a}$ & $0.9 \mathrm{~b}$ & $19.7 \mathrm{~b}$ \\
\hline \multicolumn{5}{|c|}{ Combined analysis of all trials } \\
\hline Ruddy & $20.8 \mathrm{a}$ & $10.4 \mathrm{a}$ & $1.2 \mathrm{~b}$ & $32.2 \mathrm{ab}$ \\
\hline Beauregard & $24.5 \mathrm{a}$ & $11.3 \mathrm{a}$ & $4.5 \mathrm{a}$ & $39.7 \mathrm{a}$ \\
\hline Jewel & $18.9 \mathrm{a}$ & $9.3 \mathrm{a}$ & $0.9 \mathrm{~b}$ & $29.1 \mathrm{~b}$ \\
\hline Reg al & $22.1 \mathrm{a}$ & $8.6 \mathrm{a}$ & $2.1 \mathrm{ab}$ & $33.2 \mathrm{ab}$ \\
\hline
\end{tabular}

${ }^{2}$ Trial planted in Blackville, S.C., in a randomized complete-block design with four replications, 25 plants per plot, a $30.5-\mathrm{cm}$ spacing and $114.3 \mathrm{~cm}$ between rows.

yUS \#1s: roots 5.0 to $8.9 \mathrm{~cm}$ in diameter; length of 7.6 to $23.0 \mathrm{~cm}$; roots must be well shaped and free of defects.

${ }^{x}$ Canners: roots 2.5 to $5.0 \mathrm{~cm}$ in diameter, 5.0 to $17.8 \mathrm{~cm}$ in length.

wJumbos: roots that exceed the diameter, length and with requirements of the above two grades, but are of marketable quality.

"TMY: Total marketable yield in $\mathrm{t} \cdot \mathrm{ha}^{-1}=$ yield of US\#1s + Canners + Jumbos (no culls included).

"Mean separation within columns and locations by Duncan's new multiple range test $(P=0.05)$.

Jones, A., P.D. Dukes, and J.M. Schalk. 1986. Sweetpotato breeding. In: M.J. Bassett (ed.). Breeding vegetable crops. AVI, Westport, Conn.

Jones, A., J.M. Schalk, and P.D. Dukes. 1981. Progress in selection for resistances in sweetpotato to soil insects of the WDS complex, $\mathrm{p}$. 337-344. In: R.L. Villareal (ed.). Proc. First Intl. Symp. Sweetpotato.
McLaurin, W.J. 1997. National sweetpotato collaborators evaluation. In: W.J. McLaurin (ed.). Natl. Sweetpotato Collaborators Prog. Rpt. 1997. Univ. of Georgia Agr. Expt. Sta., Athens. 5-31. McLaurin, W.J. 1998. National sweetpotato collaborators evaluation. In: W.J. McLaurin (ed.). Natl. Sweetpotato Collaborators Prog. Rpt. 1998. Univ. of Georgia Agr. Expt. Sta., Athens. 5-27. 